CORPUS $\begin{aligned} & \text { Corpus } \\ & \text { Archivos virtuales de la alteridad americana }\end{aligned}$

Vol. 10, No. 1 | 2020

Enero / Junio 2020

\title{
Un héroe para la Bonaerense
}

José Garriga Zucal

\section{(2) OpenEdition}

\section{Journals}

Electronic version

URL: http://journals.openedition.org/corpusarchivos/3421

DOI: 10.4000/corpusarchivos.3421

ISSN: 1853-8037

\section{Publisher}

Diego Escolar

\section{Electronic reference}

José Garriga Zucal, « Un héroe para la Bonaerense », Corpus [En línea], Vol. 10, No. 1 | 2020, Publicado el 28 junio 2020, consultado el 02 julio 2020. URL : http://journals.openedition.org/corpusarchivos/ 3421 ; DOI : https://doi.org/10.4000/corpusarchivos.3421

This text was automatically generated on 2 July 2020.

Licencia Creative Commons: Atribución-NoComercial 2.5 Argentina (CC BY-NC 2.5 AR) 


\title{
Un héroe para la Bonaerense
}

\author{
José Garriga Zucal
}

1 El Museo Policial de la provincia de Buenos Aires está hace más de 60 años en una vieja casona de dos plantas pintada de blanco en la zona céntrica de la ciudad de La Plata. Dos banderas, la nacional y la provincial, cuelgan de un enrejado que separa la casa de la calle. Un viejo escudo en el dintel de la puerta enrejada nos advierte que allí hay un museo, y un cartel más moderno colgado en la casona lo confirma. Un pequeño patio separa la reja de entrada de la puerta del Museo; allí un busto de Juan Vucetich nos da la bienvenida. Sobre él retornaremos con más profundidad. Pronto a cumplir cien años, fundado en 1923, el Museo tiene desde 1978 el nombre de "Inspector Mayor Dr. Constantino Vesiroglos", en honor a su fundador. Sin embargo, la figura prominente del Museo es Juan Vucetich y ni un cartel recuerda a Vesiroglos. La página web de la Policía de la Provincia de Buenos Aires, comúnmente llamada "la Bonaerense", indica el nombre del museo que desaparece en el mismo museo. Por el contrario, la figura de Vucetich acapara todas las menciones en el mundo virtual y también en el real. En la galería que recorremos hasta la entrada del Museo nos encontramos con varias placas de bronce que conmemoran nuevamente a Vucetich y su legado para con la Policía Bonaerense.

El Museo tiene en la planta baja dos salas de acceso a los visitantes y el archivo histórico con acceso restringido. En tono confidencial, el guía nos cuenta que el Museo tiene muy poco presupuesto y que están esperando unas chapas solicitadas hace mucho tiempo para reforzar el techo y evitar inundaciones en el archivo. Las paredes descascaradas por la humedad son una muestra del escaso presupuesto. En la planta alta hay otra sala y un salón de usos variados, donde en algunas oportunidades se exponen pinturas $u$ obras plásticas de artistas locales. Las tres salas son de exposición permanente y el salón tiene exposiciones temporales o transitorias. Pocas visitas son el escenario recurrente, según los guías policiales.

3 En la planta baja el recorrido se inicia en la sala "Dr. Atilio Milanta". Aquí se intenta presentar y representar la historia de la fuerza bonaerense. Tres paneles de información señalan eventos significativos de la historia de la policía en relación con hechos destacados para la nación argentina. En esta primera sala hay una vieja bomba 
de agua manual utilizada por los bomberos; un escritorio y una enorme biblioteca representan el despacho de un jefe de Comisaría de la década del '50. Un cuadro del general San Martín y un crucifijo de madera cuelgan de la pared detrás del escritorio y de dos hermosas sillas. La lujosa biblioteca atiborrada de libros y el reluciente escritorio brillan en el contraste del mobiliario despojado de las comisarías actuales. Recrean y crean un pasado glorioso e intelectual. La comunicación institucional de la Bonaerense, en un breve video - que podemos ver en YouTube-, señala el legado de la investigación criminalística para la historia policial. La recreación del despacho del jefe de comisaría busca construir esa memoria. En esa misma sala aparecen los uniformes de los primeros cuerpos de la fuerza y una antigua cámara de fotos. Es interesante señalar que la sala, "Dr. Atilio Milanta", fue nombrada de esta manera en reconocimiento a un abogado, escritor, profesor de la escuela de policías y creador de la Fundación Juan Vucetich.

En la misma planta está la segunda sala, se llama "Comisario Inspector Carlos Fontana". Dos motos, una bicicleta, muchos uniformes y muchísimas armas. Vitrinas con fusiles, pistolas, ametralladoras, espadas y cuchillos, acompañan a los uniformes, las tonfas y las esposas. Un moderno chaleco antibalas. En otra vitrina se exhiben charreteras que enseñan las jerarquías del mundo policial; junto a ella se exponen las herramientas de trabajo del escuadrón de explosivos. En el centro de la sala hay una enorme ametralladora de pie, dorada, inmensa. Esta segunda sala cambió en los últimos años y se centró en las armas y uniformes que utilizó la policía a lo largo de su historia. La ametralladora que ocupa el centro de la sala acapara la atención de los no visitantes. El guía, que me acompaña en esta visita íntima, dice que en los últimos años se eligió exhibir más armas como estrategia de conquista de públicos esquivos.

Subiendo está la sala de exposiciones temporarias y la sala "Juan Vucetich". En la de exposiciones temporarias hay exhibidas pinturas de dos artistas locales. Un pequeño escenario señala que allí se realizan ocasionalmente eventos musicales o entregas de premios. En la última un panel recorre la vida de Juan Vucetich y la invención de la dactiloscopía. En el centro, una figura de cera representa a Vucetich estudiando en su escritorio, mientras a sus espaldas dos enormes vitrinas guardan numerosas impresiones de huellas digitales. En la misma sala está escenificada la escena de un crimen que fue el hito que validó la técnica inventada por Vucetich. Francisca Rojas, en junio de 1892, asesinó a dos de sus hijos y responsabilizó a un vecino por el crimen, pero la investigación descubrió una marca de su pulgar ensangrentado en la escena del mismo. A través del estudio de las huellas dactilares se pudo resolver este crimen y el sistema de identificación desarrollado por Vucetich se difundió por el mundo. Esta técnica es fuente de prestigio y reconocimiento tanto para él como para la Policía de la Provincia de Buenos Aires.

\section{Juan Vucetich, el héroe}

Todo museo es una selección, un recorte. La reconstrucción de una historia selectiva. El Museo Policial de la Provincia de Buenos Aires tiene como objeto vincular a la policía con la investigación, con la criminalística. El Ministerio de Seguridad de la provincia de Buenos Aires exhibe un video (en YouTube) donde se sostiene que en sus orígenes el Museo estaba orientado a la criminología. El objetivo fundacional sigue vigente. En el Museo se anudan los hilos que vinculan el accionar policial con las funciones de 
pesquisa; se elije una función y esa elección opaca otras formas del hacer policial. Para la eficacia de esta operación rescata una figura, la visibiliza y engrandece.

7 El héroe de este Museo es un científico. Vucetich nació en Croacia en 1958, donde algunos dicen que estudió antropología sin que haya registro de sus estudios. En 1882 emigra a la Argentina, a la ciudad de La Plata, y se incorpora a las filas de la Policía de la Provincia de Buenos Aires. Pasa rápidamente por distintas tareas hasta recalar en la Dirección de Estadísticas; allí crea la oficina de identificación antropométrica. Luego inicia sus investigaciones en el área de la dactiloscopia. Aquí lo que hace es mejorar los métodos de identificación existentes.

pale de reconocidos investigadores - desde Darwin hasta Galton-. Los hallazgos de Vucetich son representados como hitos revolucionarios en las formas de investigación policial. En una vitrina se exhibe una revista científica francesa donde aparecen publicadas las pesquisas de nuestro héroe; la internacionalización de su saber es señal de orgullo.

Vucetich tiene un lugar protagónico en la construcción de la identidad policial. La escuela de policías de la provincia de Buenos Aires lleva su nombre. Hasta 1989 Vucetich tenía su museo, diferente al policial, resaltando su figura. Ahora ambos museos están fusionados y el Museo Policial, según su página web, resguarda los archivos del croata y se presenta como custodio de su legado.

10 Pero no solo la escuela de policías lleva su nombre. También se multiplican las placas recordativas donde se lo enaltece, presentándolo como un sabio y enmarcando su reconocimiento internacional. La Bonaerense no presenta en su Museo ni caídos en servicio, ni actos heroicos, ni muestras de arrojo. Hace hincapié en la investigación, en los uniformes y en las armas, pero principalmente en la investigación, y para ello crea a su héroe: Juan Vucetich.

\section{Recortes mutantes}

11 Decíamos que todo museo es una selección de la historia. El Museo Policial decidió exhibir un legado científico para ubicar su accionar alejado de toda represión, de los abusos, de las formas cotidianas y recurrentes de la violencia institucional. En esta representación de su historia es lógico que no aparezca una picana entre sus vitrinas, ni aparezcan imágenes del comisario Miguel Etchecolatz, quien fue director de Investigaciones, pero recordado y enjuiciado por sus crímenes en la última dictadura argentina (1976-1983). Los pocos visitantes que recorren las salas del Museo se encuentran con una historia de la Bonaerense exenta de abusos, desapariciones y asesinatos. Una policía sin máculas. Entiendo esta selección como negación/olvido/ invisibilización de una dimensión de la historia policial, relevante y recurrente, que podría haber sido exhibida.

La selección no resulta extraña. Las instituciones -al igual que los sujetos- suelen tener una reflexión parcial sobre su accionar; lo que resulta extraño es que esta reflexión no haya sido intervenida. Aquí hay un punto para la reflexión: la historia de la policía es contada por policías. Una historia no discutida en estos espacios. La Comisión Provincial por la Memoria (CPM) instaló en muchas comisarías de la provincia de Buenos Aires grandes carteles donde se anuncia que en esos espacios se violaron los 
derechos humanos durante la última dictadura. El Museo ha quedado fuera de esas intromisiones. Aislado. Reproduciendo un relato inmaculado de su accionar.

Por otro lado, observamos en la comparación de la muestra actual con fotografías y videos de muestras de antaño, que las armas han ganado un lugar protagónico. Nuestro guía señalaba que era una estrategia para interpelar a los públicos esquivos. Sin embargo, esta mutación del recorte histórico ilumina un perfil menos investigativo y más vinculado a las tareas policiales de persecución del delito, tal y como entiende el delito y los quehaceres policiales esta fuerza de seguridad. Otro recorte opera aquí, el que define qué hace un policía: cazar delincuentes (Garriga, 2016). El Museo muta para esos lares, orientado por un espíritu de época, que se sostiene en la guerra contra la delincuencia (Chevigny, 2002; Tiscornia y Sarrabayrrouse, 2004). Guerra que se puede realizar con la enorme ametralladora de pie que acapara la atención en la segunda sala.

\section{BIBLIOGRAPHY}

Chevigny P. (2002). Definiendo el rol del policía en América Latina. En J. Méndez, G. O’Donnell y P. Pinheiro (Comps.), La (in)efectividad de la ley y la exclusión en América Latina, (pp. 59-78). Buenos Aires: Paidós.

Garriga Zucal, J. (2016). El verdadero policía y sus sinsabores. Esbozos para una interpretación de la violencia policial. La Plata: EDULP.

Tiscornia, S. y Sarrabayrouse Oliveira, M. J. (2004). Sobre la banalidad del mal, la violencia vernácula y las reconstrucciones de la historia. En S. Tiscornia (Comp.), Burocracias y violencia: estudios de antropología jurídica, (pp. 63-74). Buenos Aires: Antropofagia.

\section{AUTHOR}

\section{JOSÉ GARRIGA ZUCAL}

Universidad Nacional de San Martín, Instituto de Altos Estudios Sociales y Consejo Nacional de Investigaciones Científicas y Técnicas, Argentina.

Correo electrónico: garrigajose@hotmail.com 